\title{
Determination of the serum iron-binding capacity
}

\author{
N. J. M. BIRDSALL, D'A. KOK, AND F. WILD \\ From the Department of Medicine, University of Cambridge
}

SYNOPSIS A colorimetric and an isotopic method for determining the iron-binding capacity are described, using only $1 \mathrm{ml}$. samples of plasma or serum. Both methods are simple, rapid and sensitive. Satisfactory results are obtained from frozen as well as from fresh samples.

A simple colorimetric method for estimating the iron content of plasma, using an ethanolic solution of bathophenanthroline to form a coloured iron complex under controlled conditions, has been described by Kok and Wild (1960).

The procedure, which gives accurate results, has been employed in measuring the total iron-binding capacity of plasma or serum after the iron-binding protein has been saturated by the addition in vitro of an excess of ammonium ferric citrate and the unbound excess has been removed by a basic anion exchange resin. This technique was used first by Peters, Giovanniello, Apt, and Ross (1956), whose findings are confirmed by the data recorded in this paper.

An isotopic method of measuring the total ironbinding capacity, also based on the technique of Peters et al. (1956), has been described by Bothwell, Jacobs, and Kamener (1959). A modification of their method, using the same reagents necessary for the colorimetric procedure described in this paper, is shown to give satisfactory results.

\section{REAGENTS}

IRON-FREE WATER Water, distilled twice over glass, was passed through an Elgastat B102 deionizer. The resistance of this water was greater than $6 \times 10^{6} \mathrm{ohms} / \mathrm{cm}$.

AMMONIUM FERRIC CITRATE AnalaR ammonium ferric sulphate, $0.430 \mathrm{~g}$., was dissolved in water and ferric hydroxide precipitated by dilute ammonia. After centrifuging the precipitate was dissolved on warming with a few crystals of citric acid. The $p \mathrm{H}$ of the solution was adjusted to 6.5 to $7^{1}$ by the addition of dilute ammonium hydroxide and the solution diluted to 1 litre. The solution, containing $50 \mu \mathrm{g}$. $\mathrm{Fe} / \mathrm{ml}$, , was stored at $4^{\circ} \mathrm{C}$.

Ammonium ferric- ${ }^{59} \mathrm{Fe}$ citrate (A) for the determination of the unsaturated iron-binding capacity was prepared

Received for publication 23 December 1964. by adding $0 \cdot 1 \mathrm{ml} .{ }^{59}$ ferric chloride $(5 \mu \mathrm{C}$., $1 \mu \mathrm{g}$. Fe) to $5 \mathrm{ml}$. of the above solution of ammonium ferric citrate.

BUFFER $p \mathrm{H} 7.5$ Sodium chloride, $6.4 \mathrm{~g}$., and $2.3 \mathrm{~g}$. sodium salt of diethyl barbituric acid were dissolved in 1 litre of iron-free water. Then $6.0 \mathrm{~g}$. diethyl barbituric acid was dissolved in the solution. The $p \mathrm{H}$ of the buffer was checked ${ }^{1}$ and found to be $7 \cdot 5$.

AMBERLITE IRA 410 RESIN The resin was suspended in $4 \mathrm{~N}$ hydrochloric acid for 48 hours to remove any iron and saturate the resin with chloride ions. It was washed with iron-free water, suspended in the $p \mathrm{H} 7.5$ buffer, and dried at $95^{\circ} \mathrm{C}$.

The reagents for the serum iron determination were made up as in the method of Kok and Wild (1960).

\section{APPARATUS}

All the glass used was washed in detergent solution, soaked in $50 \%$ hydrochloric acid for 48 hours, and then rinsed three times with iron-free water.

\section{PROCEDURE}

1 COLORIMETRIC METHOD (a) Serum or heparinized plasma, $1 \mathrm{ml}$., is pipetted into a $10 \mathrm{ml}$. graduated conical centrifuge tube and $0 \cdot 10 \mathrm{ml}$. of ammonium ferric citrate added. The tube is gently shaken and allowed to stand for 10 minutes at room temperature.

(b) Resin, $0.4 \mathrm{ml}$., is added and the solution stirred for five minutes. Then $5 \mathrm{ml}$. of the buffer is pipetted into the tube and the contents stirred for another five minutes.

(c) After centrifugation at low speed (about 1,000 r.p.m.), two aliquots of $2 \mathrm{ml}$. are analysed to give a duplicate determination of the serum iron. ${ }^{2}$

2 ISOTOPIC METHOD The procedure is followed as in (a) and (b) using ammonium ferric ${ }^{59} \mathrm{Fe}$ citrate, then. after centrifugation at low speed, $5 \mathrm{ml}$. of the supernatant liquid is counted on a suitable gamma counter. In these

${ }^{1}$ Using any suitable $p \mathrm{H}$ meter standardizing with buffers of $p \mathrm{H} 4.00$ and 7.00.

${ }^{2}$ Optical density measurements were made at $535 \mathrm{~m} / \mathrm{u}$ ung a Unicam SP 600 spectrophotometer and $10 \mathrm{~mm}$. fused glass cuvettes. 
experiments a well-type scintillation counter was used. A standard was made up by adding $0 \cdot 10 \mathrm{ml}$. ammonium ferric ${ }^{59} \mathrm{Fe}$ citrate to $6 \mathrm{ml}$. water, mixing thoroughly and then taking a $5 \mathrm{ml}$. aliquot for counting.

The unsaturated iron-binding capacity is then calculated from the following formula:

Unsaturated iron-binding capacity ( $\mu \mathrm{g} . / 100 \mathrm{ml}$. serum)

$$
=100 \times\left(\frac{x}{y}\right) \times \text { weight in } \mu \mathrm{g} \text {. of iron added as }
$$

$\mathrm{x}=$ counts per minute of sample, corrected for background radiation.

$y=$ counts per minute of standard, corrected for background radiation.

\section{EXPERIMENTAL PROCEDURES}

(a) The effectiveness of the resin in removing unbound iron was determined as follows: ${ }^{59} \mathrm{Fe}$ as ferric chloride in $0 \cdot 1 \mathrm{~N}$ hydrochloric acid was obtained from the Radiochemical Centre, Amersham. The specific activity was 5.0 $\mu \mathrm{C} . / \mu \mathrm{g}$. iron. Ammonium ferric- ${ }^{59} \mathrm{Fe}$ citrate solution (B) was made up by adding $0 \cdot 1 \mathrm{ml} .{ }^{59} \mathrm{FeCl}_{3}(5 \mu \mathrm{C}$. or $1 \mu \mathrm{g}$ : iron $)$ to $1.0 \mathrm{ml}$. (50 $\mu \mathrm{g}$. iron) ammonium ferric citrate and $4 \mathrm{ml}$. water. Of this solution, $20 \mu \mathrm{l}$. was added to the serum after $0 \cdot 10 \mathrm{ml}$. non-radioactive ammonium ferric citrate had been added. The normal procedure for absorption of the iron and $5 \mathrm{ml}$. aliquots of the supernatant liquid were used, in comparison with a standard, to measure the percentage ${ }^{59} \mathrm{Fe}$ retained by the resin (Table I). The radioactivity was measured by gamma counting on a well-type scintillation counter.

It was found that the radioactive iron exchanged with iron in the serum, thus tending to give a low value for the recovery of the iron. Only 15 seconds were allowed to elapse between the addition of radioactive iron and the addition of the resin. (b) The recovery of the iron bound to the serum was determined by incubating $20 \mu \mathrm{l}$. of ammonium ferric-을 ${ }^{59} \mathrm{Fe}$ citrate (B) with $1 \mathrm{ml}$. of serum at $37^{\circ} \mathrm{C}$. for one hour. $\Rightarrow$ Excess $(0 \cdot 10 \mathrm{ml}$.) non-radioactive ammonium ferric $\stackrel{\text { ? }}{+}$ citrate was then added to saturate the serum. Treatment with resin and precipitation of the protein were carried $\overline{0}$ out and $5 \mathrm{ml}$. of the supernatant liquid analysed for $\overline{\overline{\mathcal{S}}}$ ${ }^{59} \mathrm{Fe}$ (Table I).

The fact that iron, whether in solution or bound to 0 the resin, exchanges with iron bound to the serum $\overrightarrow{0}$ causes the results of (a) and (b) to be too low. $\vec{A}$ Severinghaus and Ferrebee (1950) apply a correction $\vec{\omega}$ factor to the concentration of a metal ion after the $\frac{\sigma}{0}$ precipitation of the protein. Assuming normal? serum contains $6 \%$ by weight and $4.5 \%$ by volume $\vec{\oplus}$ of protein (Cohn and Edsall, 1943), in a $1: 6^{+}$ dilution, this volume is $0.75 \%$ of the total. Therefore जि on precipitation of the protein the concentration of iron will increase by $0.75 \%$. However, no allowance is made for the extra increase in volume of the $\vec{c}$ protein precipitate due to the binding of the trichloracetic acid, and the total increase in concentration is probably not greater than $2 \%$.

From the results of experiments (a) and (b) it appears that the resin extracts more than $96 \%$ of the excess iron and the recovery of the proteinbound iron is in the range $98-100 \%$.

(c) A frozen sample of pooled normal serum was analysed repeatedly to test the reproducibility of the proposed method (Table II).

(d) The value of the unsaturated serum iron-binding capacity was found by using $0.1 \mathrm{ml}$. of the radioactive ammonium ferric- ${ }^{59} \mathrm{Fe}$ citrate solution (A) for the above experiment and comparing the result with a standard. This standard was made by using the same procedure 0 but not adding any resin (Table II).

TABLE I

RECOVERY EXPERIMENTS

Number of

Determinations

Frozen pooled normal serum

Absorption of excess iron by the resin

Recovery of iron on precipitation of the serum proteins

6
6

Frozen hyperproteinaemic serum

Absorption of excess iron by the resin

Recovery of iron on precipitation of the serum proteins
Mean Recovery

$96.8 \%$ $100.6 \%$

$95.2 \%$
Standard Error of Mean

$0.5 \%$

$0.7 \%$

$1.0 \%$

Estimated Standard Deviation

\section{$1.4 \%$}

$1.6 \%$

$2 \cdot 1 \%$

TABLE II

REPRODUCIBILITY OF RESULTS WITH FROZEN POOLED NORMAL SERUM

\begin{tabular}{|c|c|c|c|c|}
\hline & $\begin{array}{l}\text { Number of } \\
\text { Experiments }\end{array}$ & $\begin{array}{l}\text { Concentration of } \\
\text { Iron }(\mu \mathrm{g} . / 100 \mathrm{ml} .)\end{array}$ & $\begin{array}{l}\text { Standard Error of } \\
\text { Mean }\end{array}$ & $\begin{array}{l}\text { Estimated Standard } \\
\text { Deviation }\end{array}$ \\
\hline $\begin{array}{l}\text { Serum iron-binding capacity } \\
\text { Unsaturated iron-binding capacity using }{ }^{60} \mathrm{Fe} \\
\text { Serum iron determination }\end{array}$ & $\begin{array}{r}12 \\
3 \\
5\end{array}$ & $\begin{array}{r}323 \\
222 \\
93\end{array}$ & $\begin{array}{l}1 \\
6 \\
1\end{array}$ & $\begin{array}{r}4 \\
10 \\
3\end{array}$ \\
\hline
\end{tabular}


TABLE III

ANALYSIS OF SAMPLES OF SERA

\begin{tabular}{llr} 
Serum & Sex & $\begin{array}{r}\text { Serum } \\
(\mu g\end{array}$ \\
\hline Fresh & & \\
Normal & M & 107 \\
Normal & F & 119 \\
Normal & F & 130 \\
Normal & M & 162 \\
Normal & F & 122 \\
Normal & M & 89 \\
Normal & F & 92 \\
Normal & M & 88 \\
Normal & F & 139 \\
Normal & F & 113 \\
& & \\
Frozen & & \\
Macroglobulinaemia & M & 112 \\
Macroglobulinaemia & F & 130 \\
Myeloma & M & 245
\end{tabular}

Unsaturated Iron ${ }^{2}$-binding Total Iron-binding ${ }^{1} \quad$ Protein Content $\begin{array}{lll}\text { Capacity }(\mu \mathrm{g} . / 100 \mathrm{ml} .) & \text { Capacity }(\mu \mathrm{g} . / 100 \mathrm{ml} .) \quad(\mathrm{g} . / 100 \mathrm{ml} .)\end{array}$

g. $/ 100 \mathrm{ml}$.)

$\begin{array}{ll}239 & 338 \\ 210 & 332 \\ 172 & 315 \\ 212 & 365 \\ 199 & 309 \\ 281 & 359 \\ 235 & 337 \\ 267 & 344 \\ 221 & 376 \\ 240 & 351 \\ & \\ 191 & \\ 236 & 281 \\ 137 & 354 \\ \end{array}$

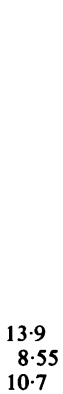

${ }^{1}$ Colorimetric determination.

${ }^{2}$ Using ammonium ferric-59 $\mathrm{Fe}$ citrate.

This difference, not significant at the $5 \%$ level, i.e., $\mathbf{P} \nless 0.05$, applying a two sample t-test, could be accounted for by the Severinghaus and Ferrebee correction.

(e) A determination of the serum iron was also carried out on the sample of pooled normal serum (Table II), and from this the unsaturated iron-binding capacity was found to be $230 \pm 1 \% \mu \mathrm{g}$. Fe/100 ml.

(f) Determinations of the serum iron and total ironbinding capacity, using the proposed methods, were carried out using fresh samples of sera. The results are indicated in Table III.

(g) Recovery experiments were also carried out using sera having a very high concentration of serum proteins. The results are shown in Table I.

\section{SUMMARY}

Both methods of estimating the iron-binding capacity of plasma or serum, which are described in this paper, are rapid, accurate, and reproducible within the limits required for clinical purposes.

The colorimetric procedure is slightly the more accurate of the two, but as the isotopic method is quicker it is recommended for use in laboratories equipped with suitable apparatus.

Satisfactory results have been obtained from normal and hyperproteinaemic sera, which have been frozen for several months.

One of us (N.J.M.B.) gratefully acknowledges the award of a Medical Research Council scholarship for training in research methods.

\section{REFERENCES}

Bothwell, T. H., Jacobs, P., and Kamener, R. (1959). S. Afr. J. med. Sci., 24, 93.

Cohn, E. J., and Edsall, J. T. (1943). Proteins, Amino Acids, and Peptides. (American Chemical Society Monographs Series No. 90.) Reinhold, New York.

Kok, D'A., and Wild, F. (1960). J. clin. Path., 13, 241

Peters, T., Giovanniello, T. J., Apt, L., and Ross, J. F. (1956). J. Lab. clin. Med., 48, 274.

Severinghaus, J. W., and Ferrebee, J. W. (1950). J. biol. Chem., 187, 621 . 